\title{
Pão sem Glúten: Busca por Novos Produtos
}

\author{
Vilmara A. Franco \& Flávio A. Silva
}

A doença celíaca (DC) é uma intolerância permanente ao glúten, caracterizada por atrofia da mucosa do intestino delgado e consequente má absorção de nutrientes. O tratamento da DC consiste na introdução de dieta sem glúten de forma permanente. $\mathrm{O}$ pão sem glúten é o produto que os celíacos gostariam de encontrar com maior facilidade no mercado permitindo ampla distribuição dos produtos com baixo custo, além da praticidade. O objetivo deste trabalho é apresentar algumas considerações sobre a doença celíaca e ingredientes para a elaboração de produtos se glúten.

Palavras-chave: Doença celíaca; intolerância; produtos de panificação.

Celiac disease (CD) is a permanent intolerance to gluten, characterized by atrophy of the small intestinal mucosa and consequent malabsorption of nutrients. Treatment of DC consists in introducing gluten diet permanently. The gluten-free bread is the product that celiacs would like to find more easily the market allowing wide distribution of products with low cost, as well as practicality. The aim of this paper is to present a review of the use of ingredients for the production of products to gluten.

Keywords: Celiac disease; intolerance; bakery products. 


\section{Introdução}

A adesão e obediência à dieta isenta de glúten requer autodeterminação por parte da pessoa com doença celíaca, bem como de seus familiares. Um estudo de usuários registrados na Associação Celíaca Brasileira (ACELBRA) mostrou que $69,4 \%$ dos participantes aderiram a uma dieta isenta de glúten ${ }^{1,2}$. Atualmente, a adesão a uma dieta isenta de glúten é considerado como a primeira linha de terapia por portadores da celíaca doença, que tem sido comprovada para aliviar os sintomas na maioria dos casos e efetivamente prevenir complicações potenciais ${ }^{3}$.

A doença celíaca é uma intolerância alimentar, enfermidade do sistema imunológico que inviabiliza o metabolismo do glúten, termo empregado para especificar as prolaminas. As frações proteicas do glúten, tóxicas ao paciente com doença celíaca, são diferentes em cada um dos cereais: gliadina no trigo, hordeína na cevada, secalina no centeio. Caso o celíaco ingira esses alimentos, ele sofrerá consequências gastrintestinais e nutricionais, podendo ocorrer perda de peso e apresentar sintomas associados à deficiência de vitaminas e minerais ${ }^{4}$. A prevalência dessa doença no Brasil é desconhecida, mas se estima a existência de um portador da doença celíaca para cada 300 habitantes $^{2}$. A quantidade de glúten tolerável varia entre as pessoas com doença celíaca. Embora não haja nenhuma evidência para sugerir um único limiar definitivo, a ingestão diária de glúten menor que $10 \mathrm{mg}$ não deve causar alterações histológicas significativas ${ }^{5}$.

No Brasil, para garantir a prática da dieta isenta de glúten foi promulgada a Lei 10.674, de 16 de maio de 2003, a qual determina que todos alimentos industrializados deverão conter em seu rótulo e bula, obrigatoriamente, as inscrições "contém Glúten" ou "não contém Glúten"6. A pesquisa realizada por Araújo e Araújo (2011) mostrou que apenas 4,8\% dos entrevistados leem os rótulos às vezes ou raramente, $\mathrm{e}$ $95,2 \%$ leem os rótulos frequentemente. O que mostra a preocupação dos celíacos com a veracidade das informações contidas nos rótulos dos produtos.

Estruturalmente, o glúten é uma rede quaternária de proteínas formada pela adição de água e energia mecânica à farinha de trigo. Essa rede proteica tridimensional é quem confere as propriedades tecnológicas de escoamento e elasticidade, ou viscoelasticidade, à massa de pães ${ }^{4}$.

O glúten com sua particular reologia tem-se mostrado como um grande desafio aos pesquisadores no desenvolvimento de produtos sem glúten. Esse engloba barreiras tecnológicas não exclusivas ao campo das matérias-primas, mas também no processamento e na vida útil. As expectativas dos consumidores para pão sem glúten são muito influenciados pelos atributos dos pães tradicionais, fazendo com que os pesquisadores e os fabricantes procurem tipos de farinhas alternativas para a farinha de trigo. No entanto, é difícil obter a qualidade desejada sem usar algum aditivo, tal como gomas, emulsificantes, ingredientes lácteos, ou fibra alimentar que tem a capacidade de imitar as propriedades viscoelásticas do glúten ${ }^{7}$. Assim, diversos pesquisadores focados no uso destes ingredientes em produtos sem glúten proporcionam possibilidades de produtos melhores no mercado.

Como ingredientes substitutos da farinha de trigo Araújo e Araújo (2011) ${ }^{2}$ relatam em sua pesquisa que os mais estudados e utilizados são: farinha de arroz, amido de milho, amido de mandioca, farinha de soja, farinha de trigo sarraceno, amido de araruta e farinha de grão de bico.

Portanto, este trabalho tem como objetivo apresentar algumas considerações sobre a doença celíaca e ingredientes para a elaboração de produtos se glúten.

\section{Doença Celíaca e seu Tratamento}

A doença celíaca é uma enteropatia provocada pela ingestão de glúten em indivíduos geneticamente susceptíveis. Representa uma das alterações genéticas mais comuns na população humana, com prevalência de $1-2 \%$ da população mundial ${ }^{8,9}$. O quadro clínico da doença celíaca é caracterizado por uma mucosa intestinal plana com a ausência de vilosidades normais, resultando má absorção generalizada de nutrientes, sendo este dano causado em pessoas susceptíveis que ingiram não apenas as proteínas do trigo, mas também as de alguns cereais como o centeio, a cevada, seus híbridos e derivados, assim como produtos alimentícios que os contenham. 
Durante a última década, estudos bioquímicos intensos têm contribuído para o progresso substancial na compreensão dos princípios gerais que determinam a patogênese desta doença $a^{10,11,12,13}$. A Figura 1 apresenta um esquema simplificado do efeito da doença celíaca na mucosa intestinal.

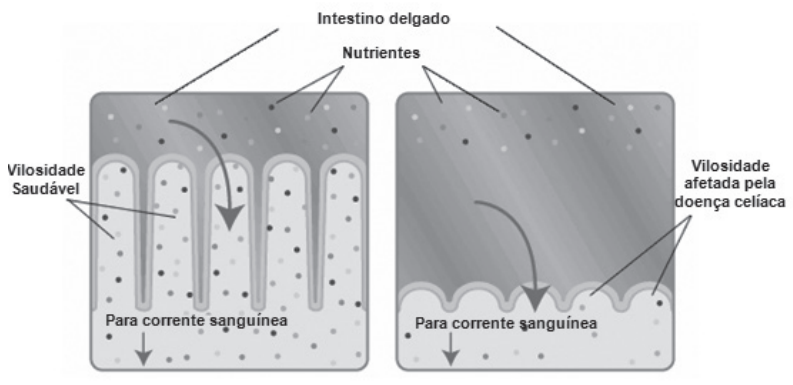

Figura 1. Efeito do consumo de glúten na mucosa intestinal de um paciente celíaco. FONTE: CHILDREN'S BOSTON GROUP, 2009141.

O tratamento da doença celíaca é fundamentalmente dietético. Consiste na exclusão do glúten, termo utilizado para descrever frações proteicas encontradas no trigo, centeio, cevada, aveia e em seus derivados. Para garantir uma dieta isenta de glúten, o celíaco deve sempre conhecer os ingredientes que compõem as preparações alimentares e fazer leitura minuciosa dos ingredientes listados nos rótulos de produtos industrializados ${ }^{3,14,15,16}$. De acordo com Sdepanian, Morais e Fagundes Neto (1999) ${ }^{17}$, para que ocorra a manifestação da doença celíaca, além do uso do glúten na dieta, é também necessária a interação com outros fatores, tais como genéticos, imunológicos e ambientais. A prevalência da doença celíaca é maior quanto mais próximos os familiares: $70 \%$ em gêmeos monozigóticos, $10 \%$ em parentes de primeiro grau e $2,5 \%$ em parentes de segundo grau, enquanto na população geral é de cerca de $1 \%{ }^{18}$.

De acordo com Protesi e Gandolfi (2005) ${ }^{19}$, é mais presente em mulheres, numa proporção de 2:1, e a anemia é um dos seus sintomas mais frequentes. É uma doença autoimune que pode potencialmente afetar qualquer órgão, e não somente o trato gastroentérico, como previamente se supunha. A sua eclosão e o aparecimento dos primeiros sintomas podem ocorrer em qualquer idade. A forma clássica da doença, com sintomatologia diretamente atribuível à má-absorção, é presentemente observada numa minoria de pacientes. A ampla gama de possíveis sintomas varia consideravelmente entre indivíduos, inclusive no mesmo indivíduo em diferentes fases da doença, o que dificulta o diagnóstico. Se não tratada, manifesta-se frequentemente de forma monossintomática, através de anemia, dermatite herpetiforme, que pode ser considerada a expressão dermatológica da doença, menarca tardia e menopausa precoce, infertilidade, abortos de repetição, hipertransaminasemia, depressão, sintomatologia neurológica progressiva, principalmente ataxia e epilepsia associadas a calcificações cerebrais, osteoporose e hipoplasia do esmalte dentário. Expressiva parcela de pacientes, principalmente, os identificados em estudos de rastreamento, relata, antes do diagnóstico, um indefinível mal-estar geral, que aceitam como seu estado normal, apresentando nítida melhora após a instituição da dieta isenta de glúten.

A manifestação da doença geralmente surge no primeiro ano de vida, época em que o bebê começa a consumir produtos com glúten, como pães e biscoitos, mas também pode aparecer na adolescência e na fase adulta. Não se sabe por que a manifestação é tardia em alguns casos, o que se conhece é que a pessoa que tem predisposição à enfermidade produz anticorpos ao glúten assim que toma contato com o ingrediente. Os anticorpos agem no intestino delgado, atrofiando-o, e o órgão perde a capacidade de absorver nutrientes, o que conduz aos problemas decorrentes da doença ${ }^{20}$.

Os mecanismos pelos quais a fração gliadina, das proteínas do trigo, dá origem a essa doença ainda são desconhecidos. As hipóteses formuladas a respeito são várias, porém não há verificação experimental concludente. Uma delas é a de que poderia haver uma insuficiência ou falta de certas enzimas intestinais, contudo, comparando-se pessoas sadias e enfermas, as diferenças enzimáticas não foram suficientemente expressivas para que a explicação pudesse ser aceita. Evidências experimentais levaram a concluir que o glúten não agride diretamente o epitélio da mucosa, mas que existe uma participação ativa do sistema imunológico no desenvolvimento da doença celíaca ${ }^{21}$.

O único tratamento eficaz para a doença celíaca consiste na supressão total e permanente das prolaminas 
presentes no trigo, centeio, cevada e aveia, visto que mesmo quantidades muito pequenas dessas proteínas podem desencadear o quadro clínico da doença ${ }^{21}$.

De acordo com Rigatto (2002) ${ }^{22}$, quando o paciente não segue a dieta, mesmo que os sintomas não apareçam (dando a falsa sensação de ter adquirido alguma tolerância ao glúten), as vilosidades intestinais estarão sofrendo uma forte agressão.

Após a retirada do glúten da dieta, a resposta clínica é rápida, havendo desaparecimento dos sintomas gastrintestinais dentro de dias ou semanas, observandose notável aumento da velocidade de crescimento do celíaco depois de pouco tempo de dieta. Embora seguir uma dieta estritamente isenta de glúten a princípio possa parecer simples, na prática evidenciam-se uma série de dificuldades na manutenção desta dieta, não somente por parte do paciente, como também de seus familiares, pois consiste em uma mudança radical do hábito alimentar ${ }^{17}$.

No Brasil, em virtude das dificuldades para garantir a prática da dieta isenta de glúten, foi promulgada, em 2003, a Lei Federal $n^{\circ} 10.674$, que obriga a que os produtos alimentícios comercializados informem sobre a presença de glúten, como medida preventiva e de controle da doença celíaca. Assim, os portadores da doença celíaca podem identificar os alimentos que não devem consumir 6 .

Para Korn $(2010)^{23}$, uma dieta saudável, sem glúten, não precisa ser sem graça ou restritiva. É por isso que a autora escreveu em sua obra "Vivendo sem glúten" várias receitas trazendo alternativas para as dietas restritas ao glúten. De acordo com Canella-Rawls (2003) ${ }^{24}$, sabe-se que atualmente existem vários produtos desenvolvidos sem glúten. O desenvolvimento deve envolver um cuidadoso e exigente processo de seleção de matériasprimas sem glúten. Durante a fase de produção também deve ser executado um contínuo controle de qualidade de alto nível.

\section{O Glúten}

O glúten é uma substância elástica, aderente, insolúvel em água, responsável pela estrutura dos produtos elaborados com farinha de trigo. Das proteínas totais do trigo, $15 \%$ correspondem a globulinas e albuminas (não formadoras de glúten) e $85 \%$ à gliadina (alta extensibilidade e baixa elasticidade) e à glutenina (baixa extensibilidade e alta elasticidade), que são formadoras de glúten. A quantidade total de proteínas existente no grão corresponde a um percentual que varia entre 8 a $21 \%$. O entrelaçamento das proteínas, obtido pela mistura com água e pelo batimento da massa, resulta em uma rede elástica, responsável pela retenção dos gases formados no processo de fermentação de massas e no de liberação de vapor de água durante o processo de cocção, que dará o volume final e a textura característica dos produtos ${ }^{25,26}$.

De acordo com Tedrus et al. (2001) 27, a gliadina apresenta peso molecular médio de 40.000, cadeia simples e é extremamente gomosa quando hidratada. Possui pouca ou nenhuma resistência à extensão e é, portanto, responsável pela coesividade da massa. A glutenina é formada por várias cadeias ligadas entre si, apresentando peso molecular médio que varia de 100.000 a vários milhões. É elástica, mas não coesiva e fornece à massa a propriedade de resistência à extensão.

A gliadina e a glutenina combinadas possuem a propriedade de formar com água e energia mecânica uma rede tridimensional viscoelástica, insolúvel em água: o glúten ${ }^{28}$.

O único cereal que apresenta gliadina e glutenina em quantidade adequada para formar o glúten é o trigo. No entanto, essas proteínas podem ainda estar presentes em outros cereais, como cevada (hordeína), centeio (secalina) e aveia (avenina) ${ }^{25,29}$.

A expressão "força de uma farinha" normalmente é utilizada para designar a maior ou menor capacidade de uma farinha de sofrer um tratamento mecânico ao ser misturada com água. Também está associada à maior ou à menor capacidade de absorção de água pelas proteínas formadoras do glúten e à capacidade de retenção do gás carbônico, resultando num bom produto final de panificação, ou seja, pão de bom volume, de textura interna sedosa e de granulometria aberta. Uma farinha de trigo forte possui, em geral, maior capacidade de retenção de gás carbônico. Uma farinha fraca, por sua vez, apresenta deficiência nesta característica. A farinha de trigo é o único produto de cereal que, misturado com água em proporção adequada, possui a habilidade de formar massa viscoelástica, capaz de reter gases e apresentar estrutura esponjosa quando aquecida no forno. Em panificação, a massa de trigo está sujeita à deformação em cada etapa do processo $^{30}$. 
A gliadina e a glutenina são a base da utilização da farinha de trigo na preparação industrial ou doméstica de produtos de panificação e de massas. Isso se deve à funcionalidade dessas proteínas, que determinam características importantes na aceitação dos alimentos, afetando significativamente sua qualidade sensorial. Tais propriedades resultam da habilidade que apresentam com respeito ao desenvolvimento de características sensoriais, cinestésicas, de hidratação, estrutural, dentre outras $^{25}$. A farinha de trigo pode ser adicionada durante $o$ processamento ou no preparo de alimentos na indústria, em domicílio ou nos serviços de alimentação. É comum a adição de trigo na produção de cafés instantâneos, achocolatados em pó, sorvetes, chicletes, sopas e papas enlatadas/desidratadas, embutidos cárneos, maioneses, molhos de tomate, mostardas, iogurtes, alimentos infantis. A presença de gliadina pode ainda ocorrer pela contaminação da farinha de trigo no ambiente, pelos utensílios, pelos manipuladores de alimentos que elaboram produtos com ou sem farinha de trigo ${ }^{25,31,32}$.

A maioria dos produtos comerciais e publicados na literatura envolve alimentos naturais isentos ou com menos de 20 ppm de glúten (partes por milhão, ou seja, miligramas por quilo). Diversas empresas produzem produtos com base no amido do trigo para que os produtos denominados "sem glúten" possam suprir a necessidade daqueles indivíduos que sofrem de desarranjos ou alergias dietéticas devido ao glúten ${ }^{33}$. Como alternativa para os celíacos, existem produtos que, de acordo com CanellaRawls $(2003)^{24}$, fazem a substituição total da farinha de trigo por aquelas conhecidas como "gluten free". Alguns exemplos são a farinha de amaranto, o amido de milho, a farinha de araruta, a farinha de arroz, farinha de grão-debico, farinha de milho, farinha de soja, fécula de batata, linhaça e tapioca. Racco $(2008)^{34}$ fala que o glúten pode ser substituído por soja, farinha de soja, flocos de soja, farinhas de arroz, milho, mandioca, polvilho doce e azedo, fécula de batata, amido de milho, creme de arroz, araruta e quinoa.

\section{Substitutos para Farinhas que Contém Glúten}

O glúten, complexo proteico responsável pela qualidade de alimentos, principalmente dos produtos de panificação ${ }^{35}$ deve ser eliminado das refeições dos portadores da doença celíaca e substituído por outras opções como farinha de arroz, amido de milho, farinha de milho, fubá, farinha de mandioca, polvilho e fécula de batata ${ }^{1}$, além das farinhas de quinoa e de amaranto.

Quando uma farinha é considerada pobre em glúten, há alternativas para enriquecê-la com melhoradores, para favorecer as propriedades gastronômicas da referida proteína. Podem ser utilizados: ácido ascórbico, palmitato de ascorbila, bromato de potássio, persulfatos, tricoleto de nitrogênio. A legislação brasileira, porém, proíbe o uso de melhoradores não fisiológicos e recomenda o ácido ascórbico, que fortalece e confere maior elasticidade ao glúten, retendo gases liberados na fermentação ${ }^{35}$. Entretanto, não havendo glúten, esses melhoradores não colaboram para a retenção de gases, o que dificulta ainda mais o preparo de alimentos para os celíacos.

Os grãos de cereais apresentam estrutura característica e diferenciada, seus envoltórios e o amido presentes caracterizam seu comportamento não só sob a ação do calor, mas também sob a ação de outros agentes ${ }^{35}$. Os cereais têm como base os carboidratos e as proteínas, que formam os constituintes principais do organismo vivo, além de serem a mais abundante e econômica fonte de energia para o homem, as proporções de amilose e amilopectina são variáveis entre os amidos procedentes de diferentes espécies vegetais e, mesmo entre amidos provenientes da mesma espécie, variam de acordo com o grau de maturação das plantas. Amidos do trigo e do milho contêm relativamente grandes quantidades de amilose (26\% a 30\%). O arroz apresenta variação de 8 a $30 \%$ de amilose, por sua vez, tubérculos como batata e mandioca contêm pequenas quantidades de amilose (17\% a $23 \%)$ e grandes quantidades de amilopectina. Portanto, em substituição à farinha de trigo, recomendase o uso de produtos que contenham características de amido semelhantes, para se promoverem características funcionais semelhantes ${ }^{28}$.

Essas proporções influenciam ainda na viscosidade e no poder de geleificação do amido. A amilose é a fração do amido que se apresenta mais viscosa, é solúvel em água e facilita a formação de géis em função da sua estrutura em forma helicoidal. A amilopectina se apresenta menos solúvel e não contribui para a formação de géis ${ }^{36}$.

A tecnologia da gelatinização do amido é de grande 
importância na indústria alimentícia, pois o aumento da solubilidade pelo processo de gelatinização é a base para a elaboração de alimentos amiláceos pré-preparados, como pudins, purê de batata, polenta entre outros. Em produtos como embutidos de carne, o amido é utilizado como estabilizante de emulsão, fato que pode prejudicar os portadores de doença celíaca, uma vez que a farinha de trigo é frequentemente usada como fonte de amido para essas preparações ${ }^{36}$.

A fécula de batata, a araruta e o polvilho não se comportam da mesma forma que o amido de milho, a farinha de arroz e a farinha de trigo, os quais formam um gel moldável. Isso ocorre porque as primeiras contêm menor quantidade de amilose, que depois de cozida e resfriada, apresenta formação de um gel firme ${ }^{35}$.

A farinha de arroz, por não conter glúten, é usada como substituto à farinha de trigo em alimentos destinados a portadores da doença celíaca e é amplamente utilizada em alimentos congelados, porque é resistente ao extravasamento do fluido do gel quando o amido da massa é congelado e descongelado ${ }^{37}$. Ressalta-se que a farinha de arroz é considerada um subproduto do beneficiamento deste cereal, uma vez que os grãos quebrados têm pouca utilização industrial e que a possibilidade do uso desta farinha na produção de pães aumenta seu valor agregado ${ }^{27}$.

A farinha de milho contém uma proteína denominada zeína, que apresenta pequena capacidade de retenção de gás e também pode conferir elasticidade às preparações ${ }^{37}$.

\section{O Pão}

Define-se pão como sendo o produto obtido pela cocção, em condições tecnologicamente adequadas, de uma massa fermentada ou não, preparada com farinha de trigo e ou outras farinhas que contenham naturalmente proteínas formadoras de glúten ou adicionadas das mesmas e água, podendo conter outros ingredientes. O produto pode ser classificado de acordo com os ingredientes e ou processo de fabricação e/ou formato ${ }^{38}$. Segundo Gray e Bemiller (2003) ${ }^{39}$, pão é uma espuma instável, elástica e sólida, que contém uma fase contínua composta, parte por uma rede de proteínas formadoras do glúten interligadas, e parte por moléculas poliméricas do amido principalmente amilose. Um pão de boa qualidade, além de se encaixar nas definições acima mencionadas, deve ser sensorialmente adequado ao consumo.
Grande parte dos produtos de panificação é composta por ingredientes que desempenham funções específicas no processo de formação da massa. Embora os constituintes possam variar em grau de importância no processo de fabricação, todos exercem determinada função. Muitas vezes, a maior ou menor importância desses ingredientes está associada com a quantidade adicionada à massa e ao tipo de produto ${ }^{40}$.

Os ingredientes básicos numa formulação de pão são: farinha, fermento biológico, sal e água. Se faltar qualquer um destes ingredientes, o produto não é pão ${ }^{41}$. Entretanto, outros componentes também podem ser adicionados tanto para mudar suas características tecnológicas, tais como melhorar o volume, a maciez, a incorporação de ar ou a durabilidade, como para conferir ao pão alguma outra característica desejada ${ }^{42}$.

\section{Função dos Ingredientes em Produtos Panificados}

A farinha de trigo é o produto obtido do endosperma amiláceo de grãos de trigo por moagem e ou outros processos tecnológicos, considerados seguros para produção de alimentos ${ }^{43}$.

A farinha de trigo é o componente estrutural mais importante dos pães, sendo responsável por fornecer as proteínas formadoras de glúten. Essas proteínas, ao se combinarem com a água, são hidratadas, gerando pontes de ligação entre elas e, mediante a batedura, formam a estrutura viscoelástica da rede de glúten ${ }^{42}$.

O sal, além de conferir e acentuar o sabor desejável de outros componentes, apresenta também função estrutural, contribui para a fixação da água no glúten. Para os biscoitos doces, reduz-se sensivelmente o teor de sal das formulações, não somente em função do sabor, mas especialmente pela ação aglutinante deste sobre as proteínas formadoras do glúten, o que em excesso é indesejável ${ }^{44}$.

De acordo com Queiroz $(2001)^{45}$, devido a sua propriedade higroscópica, o sal influencia na conservação do pão: em ambiente seco reduz o seu ressecamento e em ambiente úmido, favorece o amolecimento da crosta.

Por outro lado, o excesso de sal adicionado à formulação resultará em pães com baixo volume, crosta escura e sem abertura de pestana ${ }^{46}$. A taxa normal de adição de sal é em torno de $2 \%$ do peso da farinha, mas 
se há presença de açúcar, e, em especial, de altos níveis de açúcar, o nível de sal pode ser reduzido para $1 \%{ }^{47}$.

As gorduras também tornam a massa mais macia, melhorando a textura do miolo e contribuindo para retardar o envelhecimento do pão, fazendo com que este fique macio e palatável por um período de tempo mais longo ${ }^{48}$.

As gorduras atuam ainda sobre o sabor (principalmente as gorduras animais) e sobre o valor nutricional. Em massas para pão, é usada na concentração média de $3 \%$ sobre a farinha ${ }^{49}$. Porém, quantidades excessivas de gordura são prejudiciais, pois dificultam a hidratação e o desenvolvimento do glúten ${ }^{50}$.

A principal atuação do açúcar é no processo de fermentação, em que o fermento transforma este em gás carbônico e álcool, conferindo ao pão seu volume. Outra função do açúcar é de proporcionar a cor dourada, característica da crosta dos pães, bem como de contribuir para o aroma e sabor do produto final ${ }^{41,42}$.

As características como textura, aspecto do miolo e volume do pão feito com farinha mista podem ser favorecidas pelo aumento nas porcentagens de açúcar ${ }^{42}$. A adição de pouco açúcar à massa resultará em um pão com crosta muito clara e pouco volume e o excesso, crosta escura, miolo pegajoso e baixa absorção de água ${ }^{46}$.

Com relação ao fermento biológico, de acordo com Damodaran; Parkin, Fennema $(2010)^{36}$, a levedura Saccharomyces cerevisiae, utilizada como fermento em panificação, metaboliza açúcares como glicose, frutose, sacarose e maltose, sob condições anaeróbias, produzindo gás carbônico $(\mathrm{CO} 2)$, necessário para o crescimento da massa e para a obtenção de compostos aromáticos característicos de produtos de panificação fermentados. A reação de fermentação é dada por (1):

$$
\mathrm{C}_{6} \mathrm{H}_{12} \mathrm{O}_{6} \rightarrow 2 \mathrm{CO}_{2}+2 \mathrm{C}_{2} \mathrm{H}_{5} \mathrm{OH}
$$

Em relação à água, segundo Queiroz $(2001)^{45}$, o uso de quantidade correta deste líquido é importante no preparo de pão, porém é difícil especificar sua quantidade por causa das variações na sua absorção pela farinha.

A água é também um ingrediente imprescindível na formação da massa. Ela hidrata as proteínas da farinha de trigo tornando possível a formação da rede de glúten. A água atua também como solvente e plastificante permitindo que, durante o processo de cozimento do pão, ocorra o fenômeno de gelatinização do amido $^{45,48}$.

As funções da água na panificação são possibilitar a formação do glúten, controlar a consistência e temperatura da massa, dissolver os sais, suspender e distribuir os ingredientes, possibilitar a ação das enzimas e controlar a maciez e palatabilidade do pã $0^{50}$.

Os emulsificantes possuem estrutura molecular composta por uma extremidade hidrofílica e outra hidrofóbica, proporciona a formação de micelas, composto que possui características polares e apolares simultaneamente, pelo envolvimento de gotículas do elemento lipofílico da mistura por moléculas do emulsificante e este envolvido pela substância hidrofílica, e assim sucessivamente, dispersando as substâncias por toda a mistura ${ }^{44}$.

Os emulsificantes utilizados em panificação têm a finalidade de retardar o envelhecimento dos pães, melhorar o manuseio e a força da massa, aumentar a tolerância ao tempo de descanso e de fermentação, entre outras características. Os emulsificantes têm a capacidade de reduzir a tensão interfacial entre as fases que normalmente não se misturam ${ }^{51}$. Nos biscoitos, os emulsificantes destinam-se à estabilização das massas, dando tolerância à fermentação nos processos do tipo cream cracker, além de conferir melhor textura a todos os tipos de biscoitos. Dentre os emulsificantes utilizados em produtos de panificação, destacamse a lecitina de soja, mono e diglicerídeos de ácidos graxos, éster de ácido tartárico diacetilado com mono e diglicerídeos e lactatos ${ }^{44}$.

As enzimas mais utilizadas são amilases e proteases. A enzima alfa-amilase atua sobre as moléculas de amilose e amilopectina, quebrando-as em cadeias menores denominadas dextrinas. A betaamilase atua somente nas extremidades das cadeias de amilose e amilopectina, formando moléculas de maltose ${ }^{51}$.

As proteases são enzimas que quebram ligações peptídicas entre os aminoácidos das proteínas. Têm sido utilizadas em biscoitos para melhorar a flexibilidade das massas, tornando-as mais fáceis de laminar. Em geral, elas melhoram as características físicas das massas e do produto acabado. 
Léon, Durán e Barber (2002) $)^{52}$ estudaram a influência de misturas de enzimas contendo alfa-amilase e lipase em formulações de pães ao longo do tempo e verificaram um efeito benéfico na manutenção das propriedades sensoriais e na firmeza do pão. A retrogradação do complexo amilopectina foi inibida pelo uso das enzimas.

Dentre os melhoradores de farinha, os agentes oxidantes são os produtos de maior importância na tecnologia de panificação. Eles atuam diretamente sobre a estrutura das proteínas do glúten, reforçando a rede de glúten através da formação de ligações dissulfídicas. Estas ligações formadas afetam a reologia da massa, aumentando a resistência à extensão e diminuindo a extensibilidade. Como consequência direta da ação reforçadora dos oxidantes sobre o glúten, a capacidade de retenção de gases é aumentada, o que resulta em pães com maior volume. Os agentes oxidantes também aumentam o "oven-rise", ou salto de forno, aumento rápido de volume que ocorre nos primeiros minutos após a massa entrar no forno ${ }^{48}$.

O glúten com sua reologia ímpar tem-se mostrado como um grande desafio aos pesquisadores de pães sem glúten. Para tanto, vários estudos mostram a aplicação de farinhas sem glúten no desenvolvimento de pães sem glúten.

\section{Função do Amido na Paníficação}

$\mathrm{O}$ amido apresenta grande importância nutricional e industrial. Encontra-se amplamente distribuído em diversas espécies vegetais, como carboidrato de reserva, sendo abundante em cereais, em raízes e tubérculos. É a fonte mais importante de carboidratos na alimentação humana, representando $80-90 \%$ de todos os polissacarídeos da dieta, e o principal responsável pelas propriedades tecnológicas que caracterizam grande parte dos produtos processados ${ }^{53}$.

O amidoé um polissacarídeo constituído de duas formas poliméricas de glicose: amilose, que é essencialmente linear, com ligações $\alpha$ (1-4) e a amilopectina, uma molécula altamente ramificada, composta por unidades de glicose ligadas em $\alpha-1,4$ e $\alpha-1,6$, sendo esta última a responsável pela ramificação da molécula ${ }^{54}$. As proporções em que essas estruturas aparecem diferem em relação às fontes botânicas, variedades de uma mesma espécie e, mesmo numa mesma variedade, de acordo com o grau de maturação da planta ${ }^{55}$.
A amilopectina é, estrutural e funcionalmente, a mais importante das duas frações, pois sozinha é suficiente para formar o grânulo. Quanto à amilose, acredita-se que ela esteja localizada entre as cadeias da amilopectina e aleatoriamente entremeada entre as regiões amorfas e cristalinas. As moléculas de amilose maiores estão concentradas no centro do grânulo e, provavelmente, participam das duplas hélices com a amilopectina, enquanto as moléculas menores presentes na periferia podem ser lixiviadas para fora do grânulo. Apesar de seu limitado papel na formação de cristais, a amilose pode influenciar a organização das duplas hélices, interferindo na densidade de empacotamento das cadeias de amilopectina ${ }^{55}$.

Nos pães e em outros produtos de panificação, é muito importante compreender o comportamento do amido. Quando a farinha é moída, inevitavelmente, uma proporção significativa de grânulos de amido é fisicamente danificada, rachada ou quebrada. Quando a massa é primeiramente misturada, esses grânulos de amido absorvem alguma água. Durante o fabrico do pão, os estágios de amassadura e fermentação anteriores à cozedura dão tempo para que as $\alpha$ e $\beta$ - amilases, que estão presentes naturalmente na farinha, transformem uma pequena proporção do amido em maltose e outros açúcares. Estes são fermentados pelas leveduras que produzem $\mathrm{CO}_{2}$ na massa. Uma vez no forno, os grânulos de amido gelatinizam e sofrem graus variados de disrupção e dispersão ${ }^{56}$.

\section{A Batata-Doce e Seus Derivados}

\section{IMPORTÂNCIA SOCIOECONÔMICA DA BATATA-DOCE}

A família das Convolvuláceas agrupa aproximadamente 50 gêneros e mais de 1000 espécies. Dentre estas espécies, somente a batata-doce (Ipomea batatas L.) tem cultivo de expressão econômica ${ }^{57}$. No Brasil, a área plantada com batata-doce, em 2010, foi de 41.999 ha, com um rendimento médio de $11.846 \mathrm{~kg} / \mathrm{ha}$, colhendo aproximadamente 495.182 toneladas de raízes. O Rio Grande do Sul, em 2010, foi o maior produtor de batata-doce, com 154.071 toneladas, que representam aproximadamente $31 \%$ da produção nacional. A área colhida com batata-doce no Rio Grande do Sul foi de 12.576 ha, com um rendimento médio de $12.251 \mathrm{~kg} / \mathrm{ha}$, 
enquanto que em Goiás a área plantada e colhida foi de $35 \mathrm{ha}$, com um rendimento de $5.486 \mathrm{~kg} / \mathrm{ha}^{58}$.

O cultivar é bem disseminado em todas as regiões brasileiras, apresenta certa relevância econômica e é uma hortaliça de ampla aceitação popular, cultivada na maioria das vezes, por pequenos produtores rurais em sistemas agrícolas com reduzida utilização de insumos, sendo consumida principalmente assada ou cozida e industrializada na forma de doces ${ }^{59}$.

A batata-doce apresenta as seguintes características: é resistente à seca, é de fácil cultivo; apresenta baixo custo de produção; permite colheita prolongada; apresenta resistência a pragas e doenças; é mecanizável e protetora do solo, sendo desta forma considerada rústica. Entretanto, quando comparada com o arroz, milho, banana e sorgo, e cultivada em regiões tropicais, é mais eficiente em termos de quantidade de energia líquida produzida por unidade de área e por unidade de tempo. Isso ocorre porque a planta produz grande quantidade de raízes em um ciclo relativamente curto (120 a 150 dias) a um custo baixo, durante o ano inteiro ${ }^{59}$.

A comercialização da batata-doce como hortaliça exige um padrão de tamanho, e não aceita manchas e cicatrizes na casca. Assim sendo, as raízes maiores, com cicatrizes e manchas na casca poderiam ser utilizadas como matérias-primas na produção de produtos alimentícios diferenciados. Considerando que cerca de $20 \%$ da produção de raízes de batata-doce não são comercializadas, devido à falta de padrão, têm-se em média, uma perda de 54.000 toneladas por ano $^{60}$.

\section{COMPOSIÇÃO NUTRICIONAL DA BATATA-DOCE}

A batata-doce é fonte de energia, conforme Tabela 1, minerais e vitaminas, apresenta composição química que varia com a cultivar, condições climáticas, época de colheita, tratos culturais, condições e duração de armazenamento. Ao ser colhida, apresenta cerca de $30 \%$ de matéria seca que contém em média $85 \%$ de carboidratos cujo componente principal é o amido. Comparada com outras estruturas vegetais amiláceas, possui maior teor de matéria seca, carboidratos, lipídeos, cálcio e fibras que a batata inglesa, mais carboidratos e lipídeos que o inhame, e mais proteína que a mandioca. Durante o armazenamento, parte do amido se converte em açúcares solúveis, atingindo de 13,3 a $29,2 \%$ de amido e de 4,8 a $7,8 \%$ de açúcares totais redutores ${ }^{61}$.

Aliado ao suprimento de vitaminas principalmente as do grupo A e B, torna-se um importante complemento alimentar para famílias de baixa renda, quando se compara com a composição do arroz, que é a base alimentar dessa classe social ${ }^{62}$. O conteúdo de aminoácidos de farinha de batata-doce, segundo IWE et al. (2001) ${ }^{63}$ apresenta valores altos de ácido glutâmico, seguido de ácido aspártico, leucina e outros (prolina, arginina, lisina, valina etc).

A raiz tuberosa de batata-doce é um alimento à base de carboidratos sendo seu mais importante constituinte o amido. Os grânulos de amido de batata-doce podem apresentar os formatos arredondado, facetado $\mathrm{e}$ poliédrico, apresentando em sua maioria a última das formas mencionadas. $\mathrm{O}$ hilum é normalmente cêntrico,

Tabela 1. Composição média de $100 \mathrm{~g}$ de matéria fresca de batata-doce, mandioca, batata inglesa e inhame.

\begin{tabular}{|c|c|c|c|c|c|}
\hline \multirow{2}{*}{ Componente } & \multirow{2}{*}{ Unidade } & \multicolumn{4}{|c|}{ Quantidade } \\
\hline & & Batata-doce & Mandioca & Batata inglesa & Inhame \\
\hline $\begin{array}{l}\text { Umidade (base } \\
\text { úmida) }\end{array}$ & $\%$ & 70 & 63 & 78 & 72 \\
\hline Carboidratos totais & $\mathrm{g}$ & 26,1 & 32,4 & 18,5 & 23,1 \\
\hline Proteína & $\mathrm{g}$ & 1,5 & 1,0 & 2,1 & 1,7 \\
\hline Lipídeos & $\mathrm{g}$ & 0,3 & 0,3 & 0,1 & 0,2 \\
\hline Cálcio & $\mathrm{mg}$ & 32 & 39 & 9 & 35 \\
\hline Fósforo & $\mathrm{mg}$ & 39 & 41 & 50 & 65 \\
\hline Ferro & $\mathrm{mg}$ & 0,7 & 1,1 & 0,8 & 1,2 \\
\hline Fibras digeríveis & $\mathrm{g}$ & 3,9 & 4,4 & 2,1 & 4,0 \\
\hline Energia & kcal & 111 & 141 & 80 & 103 \\
\hline
\end{tabular}


com as cruzes de polarização variando de fortes, nos grânulos redondos, para fracas, nos grânulos poliédricos. $\mathrm{O}$ amido de batata-doce apresenta excelentes propriedades adesivas, podendo também ser utilizado como substrato para a produção de álcool e de outros produtos industriais fermentados ${ }^{64}$.

$\mathrm{O}$ amido da batata-doce pode apresentar valores de 15,7 a $21,6 \%$ de amilose ${ }^{65}$, ou $18 \%$ de amilose ${ }^{66}$. Quanto à estrutura cristalina, os tubérculos como a batata-doce apresentam amido com estrutura tipo B. O conteúdo de amilose e amilopectina e suas estruturas afetam a arquitetura do grânulo de amido, sua gelatinização, perfil de pasta e atributos texturais ${ }^{67}$.

\section{UTILIZAÇÃO DA BATATA-DOCE}

A baixa lucratividade da batata-doce acabou por evidenciar a necessidade da busca de outros caminhos mais atrativos para exploração da cultura. Apesar de apresentar um excelente potencial, com multiplicidade de uso, poucos estudos foram efetivamente realizados. Dentre as várias possibilidades de uso da cultura, podese destacar a produção de farinha ${ }^{68,69}$.

A produção de farinhas apresenta grande variabilidade para a indústria de alimentos, principalmente, em produtos de panificação, produtos dietéticos e alimentos infantis, por serem rica fonte de amido e sais minerais ${ }^{70}$.

As mudanças no processamento e a crescente exigência do consumidor por alimentos que apresentem, além da alta qualidade sensorial e nutricional, benefícios associados à saúde, fazem surgir a necessidade de novos ingredientes que possam atender a estas exigências do mercado ${ }^{71}$.

A produção de farinha de batata-doce é uma importante alternativa para a valorização da cultura, pois se trata de um processo de baixo custo e, que sendo um produto diferenciado, poderá atender a um mercado crescente de produtos naturais e para fins especiais ${ }^{57}$.

De acordo com estudos de SAMMY (1970) $)^{72}$, a incorporação de farinha de batata-doce em pães provocou algumas mudanças na cor das amostras, com escurecimento gradual à medida que se elevou o grau de substituição. A casca do pão e sua parte interna apresentaram aspecto quebradiço, que se acentua com o maior teor de farinha de batata-doce. O volume específico dos pães diminuiu com o nível de substituição, bem como a compressibilidade e a extensibilidade.

\section{O Arroz e seus Derivados}

$\mathrm{O}$ arroz é uma planta monocotiledônea da família Poaceae e espécie Oryza sativa, que se desdobra em duas subespécies, denominadas communis e brevis. A subespécie brevis compreende variedades de grãos muito curtos, cultivadas no Oriente. A subespécie communis compreende, por sua vez, dois grupos distintos: indico, com grãos longos, e japônico, com grãos curtos ${ }^{73}$.

O Brasil é o maior produtor fora da Ásia, obtendo para a safra em 2012/2013 aproximadamente 11,9 milhões de toneladas de $\operatorname{arroz}^{74}$. O arroz é um alimento básico para cerca de 2,4 bilhões de pessoas. Apenas uma pequena quantidade de arroz é consumida como ingrediente em produtos processados, sendo seu maior consumo na forma de grão. $\mathrm{O}$ arroz é uma excelente fonte de energia, devido à alta concentração de amido, fornecendo também proteínas, vitaminas e minerais, e possui baixo teor de lipídios. Nos países em desenvolvimento, onde o arroz é um dos principais alimentos da dieta, ele é responsável por fornecer, em média, $715 \mathrm{kcal}$ per capita por dia, $27 \%$ dos carboidratos, $20 \%$ das proteínas e $3 \%$ dos lipídios da alimentação. No Brasil, o consumo per capita é de $108 \mathrm{~g}$ por dia, fornecendo $14 \%$ dos carboidratos, $10 \%$ das proteínas e $0,8 \%$ dos lipídios da dieta. Portanto, devido à importância do arroz na dieta de grande parte da população, sua qualidade nutricional afeta diretamente a saúde humana ${ }^{75,76}$.

O arroz é constituído principalmente por amido, apresentando quantidades menores de proteínas, lipídios, fibras e cinzas. Entretanto, a composição do grão e de suas frações está sujeita a diferenças varietais, variações ambientais, de manejo, de processamento e de armazenamento $^{77}$, produzindo grãos com características nutricionais diferenciadas. Além disso, os nutrientes não estão uniformemente distribuídos nas diferentes frações do grão. As camadas externas apresentam maiores concentrações de proteínas, lipídios, fibra, minerais e vitaminas, enquanto o centro é rico em amido. Dessa forma, o polimento resulta em redução no teor de nutrientes, exceto de amido, originando as diferenças na composição entre o arroz integral e o polido ${ }^{78}$.

O amido é formado basicamente por dois tipos de macromoléculas, a amilose e a amilopectina, e apresentase na forma de grânulos, com formas bastante distintas. $\mathrm{O}$ amido deve muito de sua funcionalidade a estas duas 
macromoléculas, assim como à organização física delas dentro da estrutura granular. A proporção entre amilose e amilopectina é variável com a fonte botânica, a qual confere características específicas à pasta de amido ${ }^{59}$. $\mathrm{O}$ amido total presente em farinhas de arroz se divide em disponível e resistente, sendo que o amido resistente é representado pela fração não digerida no intestino delgado de indivíduos saudáveis, sendo fermentado no intestino grosso e suas propriedades são similares às da fibra alimentar. Possui efeito prebiótico e atua no metabolismo lipídico, reduzindo o colesterol e o risco de colite ulcerativa e câncer de cólon ${ }^{79,80}$.

$\mathrm{O}$ amido de arroz não possui um volume de produção expressiva, no entanto, suas características especiais deveriam ser mais bem exploradas. O pequeno tamanho dos grânulos confere uma textura extremamente suave com o cozimento e sabor brando. Não é um produto alergênico, podendo ser consumido por portadores de doença celíaca como substituto do trigo na elaboração de produtos sem glúten ${ }^{81,82}$.

A farinha de arroz pode ser obtida através da moagem dos grãos polidos inteiros ou dos quebrados, obtidos do processo de beneficiamento industrial do arroz. A moagem consiste no cisalhamento dos grãos em rolos raiados, para lhes reduzir a granulometrias menores do que $250 \mu \mathrm{m}$. Através do peneiramento, há remoção de partículas com granulometrias maiores, garantindo um produto dentro dos padrões tecnológicos, com redução e/ou eliminações de sujidades ou focos de contaminação microscópica. A farinha de arroz deve ter diâmetro inferior a $195 \mu \mathrm{m}$ para apresentar boas propriedades para panificação ${ }^{77,83}$.

A farinha de arroz é um produto versátil, pois tem gosto suave, apresenta propriedades hipoalergênicas, baixos níveis de sódio e carboidratos de fácil digestão e por isso, é uma das mais indicadas para produzir produtos sem glúten $^{84}$. No entanto, cereais sem glúten, como o arroz, não preenchem as necessidades indispensáveis para processar produtos fermentados panificáveis, pois, quando a farinha de arroz é amassada com água, não ocorre a formação de uma massa viscoelástica que retém o $\mathrm{CO}_{2}$ formado durante a fermentação e, consequentemente, o produto resultante tem baixo volume específico e apresenta características muito distintas do pão de trigo.
Para melhorar a qualidade de pães com farinha de arroz, alguns ingredientes, tais como amido modificado ${ }^{85}$, hidrocoloides ${ }^{84,86}$, outras fontes de proteína ${ }^{87,88,89,90}$ e enzimas $^{89,90,91,92,93,94}$ têm sido usados.

O desenvolvimento de farinhas que tenham melhores propriedades funcionais para poderem ser aplicadas em produtos e formulações, ou que possam ser moldadas para alimentos de conveniência, ou para fins especiais tem sido objetivo de estudo de diversos pesquisadores ${ }^{2,95}$.

Desta forma, podem ser obtidos vários novos produtos ou ingredientes a partir dos grãos quebrados e da farinha de arroz como: farinhas pré-gelatinizadas ${ }^{96,97}$, farinhas torradas ${ }^{98}$, farinhas modificadas por enzimas e farinhas lácteas ${ }^{99}$, farinhas mistas pré-gelatinizadas e macarrão ${ }^{100}$, salgadinhos extrusados ${ }^{100,101}$, extratos hidrossolúveis ${ }^{102,103}$ e filmes biodegradáveis para embalagem de alimentos ${ }^{104}$, sobremesas instantâneas ${ }^{97}$, bolos ${ }^{105}$, biscoitos, pães, entre outros.

\section{Produtos Panificados Isentos de Glúten}

Recentemente, o mercado de produto sem glúten passou por uma transformação do conceito de produtos para pessoas "doentes" para a categoria de Saúde e Bemestar, sendo uma das histórias de sucesso no mercado global alimentício. Em âmbito global, este mercado cresceu de US\$ 487 milhões em 2002 para US\$ 1,2 bilhões em 2007. A categoria de produtos sem glúten representa um quinto do mercado mundial de produtos para consumidores com intolerâncias, que também engloba alimentos sem lactose, com $60 \%$, e alimentos para diabéticos com o restante. Quando se observa o mercado de produtos de panificação para fins especiais, os produtos sem glúten somam $70 \%$ das vendas ${ }^{106}$.

A formulação de produtos panificados livres de glúten apresenta um desafio aos tecnologistas e padeiros. Isso reflete na dificuldade do desafio tecnológico e na falta de informação às pessoas que necessitam desses produtos. Nos últimos anos, foram realizadas várias pesquisas $\mathrm{e}$ desenvolvimentos mais significativos em produtos livres de glúten, utilizando amidos, produtos de laticínio, gomas e hidrocoloides, probióticos e outras combinações como alternativas ao glúten, a fim de melhorar a estrutura, paladar, aceitabilidade e vida de prateleira dos produtos ${ }^{14}$. 
Algumas opções como farinha de arroz, creme de arroz, amido de milho, farinha de milho, fubá, farinha de mandioca, polvilho doce, polvilho azedo e fécula de batata são utilizadas na fabricação de produtos de panificação sem glúten. Entretanto, essa substituição provoca mudanças sensoriais nos alimentos, modificando seu sabor, textura, hidratação e aparência ${ }^{4}$ e, muitas vezes, por estas farinhas e amidos serem refinados, apresentam baixos teores de micronutrientes e fibra alimentar, um dos fatores responsáveis pelo consumo inadequado desses nutrientes por celíacos ${ }^{107}$. Outros alimentos passaram a ser utilizados como novas opções para a fabricação de alimentos isentos de glúten e também para o aumento de seu valor nutritivo, como por exemplo, o amaranto, a quinoa e, mais recentemente, a chia ${ }^{108,109,110,111,112}$.

O maior problema da substituição dos cereais que contêm glúten por outras matérias-primas que não o contêm é o fato de que este apresenta algumas propriedades tecnológicas que conferem qualidade aos produtos, como elasticidade, coesividade e hidratação, além de contribuir para o aumento do rendimento ${ }^{113}$.

Do ponto de vista industrial, não é apenas a aceitação dos pães sem glúten, que é o problema, mas também tem sido demonstrado que os pães sem glúten têm vida útil mais curta e menos saborosos quando comparados com pães contendo glúten. Isto resulta em ausência de pão sem glúten fresco nos supermercados ${ }^{14}$.

Segundo Anton; Artfield (2008) $)^{114}$, há ainda uma necessidade de encontrar substâncias que poderiam melhorar a qualidade de pães sem glúten. Formulações de pão sem glúten com amidos, hidrocoloides, e/ou fontes de proteína têm sido investigados há mais de 40 anos.

A fim de retardar o endurecimento e, assim, melhorar a vida de prateleira do pão sem glúten pode-se aplicar gomas, emulsificantes, enzimas, ou produtos lácteos para dar a estrutura desejada, isoladamente ou em diferentes combinações ${ }^{115,116,86,117,118,119}$.

\section{Hidrocoloides}

A Resolução RDC n 45 de 03 de novembro de 2010 aprovou o Regulamento Técnico sobre aditivos alimentares autorizados segundo as Boas Práticas de Fabricação (BPF), no qual a goma xantana e guar estão inseridas ${ }^{120}$. A Resolução n. ${ }^{\circ} 383$ de 09 de agosto de 1999 aprovou o Regulamento Técnico sobre o uso de aditivos alimentares, estabelecendo suas funções e seus limites máximos para a categoria de alimentos ${ }^{7}$ - produtos de panificação e biscoitos, sendo que nela os espessantes utilizados para pães com fermento biológico estabelece como limite máximo quantun satis ${ }^{121}$.

A grande maioria das aplicações de hidrocoloides na indústria alimentar está associada à sua capacidade hidrofílica, ou seja, interagem significativamente com a água que se encontra livre no meio onde se aplicam, reduzindo a sua mobilidade e aumentando, assim, a viscosidade das soluções ${ }^{122,123}$.

Os hidrocoloides são amplamente utilizados como estabilizantes de emulsões, agentes de absorção de água, espessantes e gelificantes. Geralmente, são usados em pequenas concentrações e, em geral, não contribuem para o sabor, aroma ou valor nutricional dos alimentos ${ }^{124,125,126}$

Os hidrocoloides aumentam a viscosidade da massa, melhorando a capacidade de retenção de gás e gerando produtos com maior volume e miolos com melhores características estruturais e de textura ${ }^{127}$. Vários hidrocoloides como hidroxipropilmetilcelulose, carboximetilcelulose, gomas locuste, guar e xantana, pectina, $\beta$-glucana, estão sendo investigadas visando a melhoria das propriedades dos pães sem glúten ${ }^{7,14,116,118,86,128,129}$. No geral, os hidrocoloides são adicionados em níveis que variaram de 1 a $4 \%$ (base farinha) e os melhores resultados em termos de volume e textura foram obtidos pela incorporação de 1 a $2 \%$. Os resultados são variáveis em função da formulação e das condições de processamento.

Em geral, a escolha de um hidrocoloide é feita em função das características desejadas no produto final, mas é também influenciada pelo fator custo e regularidade no fornecimento ${ }^{126}$.

\section{CARBOXIMETILCELULOSE (CMC)}

A substituição química de algumas hidroxilas da celulose por metilas leva à formação da metilcelulose, e a substituição por grupos carboxílicos leva à formação da carboximetilcelulose (CMC), compostos de fácil dissolução e com grande capacidade espessante e estabilizante $^{126}$. A presença de substituintes com grupos - $\mathrm{CH} 2-\mathrm{COOH}$ na cadeia de celulose produz afastamento das cadeias poliméricas e permite maior penetração de 
água, conferindo a $\mathrm{CMC}$ solubilidade em água a frio (RHOR, 2007). Além disso, soluções com CMC tendem a ser altamente viscosas e estáveis, mas a viscosidade diminui durante o aquecimento ${ }^{130}$. A CMC é usada em produtos de panificação, principalmente, porque a água melhora o sabor do produto, controla as propriedades reológicas das massas à base de cereais, melhora o volume e diminui a formação de cristais de gelo ${ }^{131}$.

\section{Goma Xantana}

A goma xantana é um polissacárido extracelular secretado pela bactéria Xanthomonas campestris na superfície da parede celular durante o seu ciclo de vida normal. Na natureza, estas bactérias encontramse nas folhas dos vegetais Brassica, como o repolho. Comercialmente, a goma xantana é produzida via fermentação aeróbica, num meio contendo glicose, uma fonte de azoto e vários elementos traço. No final da fermentação, o caldo é pasteurizado para matar a bactéria e a goma xantana é recuperada pela precipitação com álcool isopropílico. Finalmente, o produto é moído, seco e embalado ${ }^{126,132}$.

Agoma xantana é bastante utilizada como estabilizante para alimentos, como cremes, sucos artificiais, molhos para saladas, carne, frango ou peixe, assim como para xaropes e coberturas para sorvetes e sobremesas. Ainda apresenta compatibilidade com a maioria dos coloides usados em alimentos, incluindo o amido, fato que a torna ideal para a preparação de pães e outros produtos para panificação ${ }^{133,134}$.

\section{INTERAÇÕES ENTRE O AMIDO E OUTROS HIDROCOLOIDES}

Como já mencionado, o amido é constituído de dois polímeros de glicose, a amilose e a amilopectina. Estes polímeros estão presentes nos grânulos na forma associada. Após a gelatinização do amido, durante o resfriamento, inicia-se um processo em que as moléculas de amilose auto associam-se, e formam um gel. Esse processo é denominado retrogradação do amido ${ }^{56}$.

Os hidrocoloides são, muitas vezes, utilizados nas formulações de pães como uma estratégia para melhorar as propriedades tecnológicas das massas e a qualidade final do pão. A adição dos hidrocoloides tem demonstrado que estes afetam o comportamento reológico da massa e o endurecimento do pão ${ }^{135}$ A gelatinização do amido na presença de diferentes hidrocoloides influencia a viscosidade da pasta de amido quente. Este comportamento tem sido explicado em termos da formação de complexos entre os polímeros de amido (amilose e amilopectina) e os hidrocoloides durante a gelatinização ${ }^{136}$.

O endurecimento refere-se a todas as alterações físicoquímicas que ocorrem nos alimentos após o cozimento, tornando o produto menos aceitável para o consumidor ${ }^{137}$. $\mathrm{O}$ endurecimento do pão é considerado um processo muito complexo, que não pode ser explicado por uma única causa. A retrogradação do amido, reorganização dos polímeros no interior da região amorfa, perda do conteúdo de umidade, distribuição de água entre a zona amorfa e a cristalina e a estrutura macroscópica do miolo devem contribuir para o processo de endurecimento ${ }^{135}$.

O fenômeno do endurecimento ainda não é completamente compreendido, embora muitos investigadores concordem que a retrogradação do amido é o fator mais importante que promove o aumento da firmeza do miolo. Investigadores que avaliaram o efeito da adição de diferentes hidrocoloides (carragenato, alginato, xantana, carboximetilcelulose e gelatina) no comportamento de endurecimento do miolo à base de farinhas isentas de glúten, mostraram que a goma xantana reduziu a firmeza do miolo nos diferentes tempos de armazenamento $(0,24 \text { e } 72 \text { horas })^{138}$. Em contraste, outro estudo verificou que o pão contendo xantana mostrou o maior valor da firmeza em comparação com os outros hidrocolóides após $24 \mathrm{~h}$ de armazenamento ${ }^{135}$. Os variados ingredientes que constituem as formulações dos pães promovem diversos efeitos sobre o endurecimento. Sendo o pão um alimento complexo, em que todos os ingredientes interagem uns com os outros, é difícil estimar os efeitos específicos dos hidrocoloides no processo de endurecimento do pão.

\section{INTERAÇÕES ENTRE OS HIDROCOLOIDES}

Bortolotto (2009) ${ }^{139}$, em seu estudo sobre o comportamento da viscosidade de sistemas de carboximetilcelulose de sódio e diferentes componentes nos produtos para indústria alimentícia, encontrou um resultado satisfatório com alguns tipos de gomas que chegaram à viscosidade desejada para os produtos 
testados. $\mathrm{O}$ estudo mostra que a interação da $\mathrm{CMC}$ com a goma xantana depende do percentual utilizado dessas duas gomas. Tanto CMC quanto goma xantana são polímeros de cadeia molecular longa, os dois polímeros são facilmente dissolvidos em água.

A goma xantana é frequentemente usada em combinação com outros hidrocoloides, inclusive com $\mathrm{CMC}$, a fim de se obter o comportamento desejado para os produtos. A sua estrutura ramificada e o alto peso molecular confere à goma xantana uma alta viscosidade. O sinergismo entre esses dois hidrocoloides é de especial interesse comercial, por possibilitar uma nova funcionalidade, além de proporcionar redução das quantidades utilizadas, diminuindo custos. A força do gel está correlacionada com o fenômeno de retrogradação, isto é, quanto maior a força, maior a retrogradação ${ }^{140}$.

\section{Referências}

1. Acelbra - Associação Brasileira de Celíacos. Disponível em: $<$ http:// www.acelbra.com.br>. Acesso em: 05 nov. 2014.

2. Araújo, H. M. C.; Araújo, W. M. C. Coeliac disease. Following the diet and eating habits of participating individuals in the Federal District, Brazil. Appetite, London, v. 57, p. 105-109, 2011.

3. Rashtak, S.; Murray, J. A. Review article: celiac disease, new approaches to therapy. Alimentary Pharmacology and Therapeutics, Malden, v. 35, n. 7, p. 768-781, 2012.

4. Almeida, O. P. Pão de forma sem glúten a base de farinha de arroz. 2011. 289 f. Tese (Doutorado em Tecnologia de Alimentos) - Faculdade de Engenharia de Alimentos, Universidade Estadual de Campinas, Campinas, 2011.

5. Akobeng, A. K.; Thomas, A. G. Systematic review: tolerable amount of gluten for people with coeliac disease. Alimentary Pharmacology \& Therapeutics, Malden, v. 27, n. 11, p. 1044-1052, 2008.

6. Brasil. Agência Nacional de Vigilância Sanitária. LEI n ${ }^{\circ}$ 10.674 , de 16 de maio de 2003. Obriga a que os produtos alimentícios comercializados informem sobre a presença de glúten, como medida preventiva e de controle da doença celíaca. Brasília, DF: ANVISA, 2003. Disponível em: < http:// www.anvisa.gov.br/e-legis/>. Acesso em: 29 mar. 2015.

7. Demirkesen, I., Mert, B., Sumnu, G.; Sahin, S. Rheological properties of gluten-free bread formulations. Journal of Food Engineering, Kidlington, v. 96, p. 295-303, 2010.

8. Husby, S. et al. European Society for Pediatric Gastroenterology, Hepatology, and Nutrition Guidelines for the Diagnosis of Coeliac Disease. Journal of Pedriatric Gastroenterology and Nutrition, Philadelphia, v. 54, n. 1, p. 136-160, 2012.
9. Nunes, M. H. B., Moore, M. M., Ryan, L. A. M., Arendt, E. K. Impact of emulsifiers on the quality and rheological properties of gluten-free breads and batters. European Food Research and Technology, New York, v. 228, p. 633-642, 2009.

10. Alvarenga, N. B., Lidon, F. C., Belga, E., Motrena, P., Guerreiro, S., Carvalho, M. J. Characterization of Gluten-free Bread Prepared From Maize, Rice and Tapioca Flours using the Hydrocolloid Seaweed Agar-Agar. Recent Research in Science and Technology, Canadá, v. 3, n. 8, p. 64-68, 2011.

11. Korus, J.; Witczak, M.; Ziobro, R.; Juszczak, L. The impact of resistant starch on characteristics of gluten-free bread and dough. Food Hydrocolloids, Oxford, v. 23, n. 3, p. 988- 995, 2009.

12. Wieser, H.; Koehler, P. The biochemical basics of celiac disease. Cereal Chemistry, St Paul, v. 85, n. 1, p. 1-13, 2008.

13. Witczak, M.; Korus, J.; Ziobro, R.; Jusckzac, L. The effects of maltodextrins on gluten-free dough and quality of bread. Journal of Food Engineering, Kidlington , v. 96, n. 2, p. 258$265,2010$.

14. Gallagher, E.; Gormley, T. R.; Arendt, E. K. Crust and crumb characteristics of gluten free breads. Journal of Food Engineering, Kidlington, v. 56, p. 153-161, 2003.

15. Ribotta, P. D.; Ausar, S. F., Morcillo M. H., Pérez G. T., Beltramo D. M., León A. E. Production of gluten-free bread using soybean flour. Journal of the Science of Food and Agriculture, Chichester, v. 84, p. 1969-1974, 2004.

16. Sainsbury, K.; Mullan, B.; Sharpe, L. Gluten free diet adherence in coeliac disease. The role of psychological symptoms in bridging the intention-behaviour gap. Appetite, London, v. 61, p. 52-58, 2013.

17. Sdepanian, V. L.; Morais, M. B.; Fagundes-Neto, U. Doença celíaca: a evolução dos conhecimentos desde sua centenária descrição original até os dias atuais. Arq. Gastroenterol, São Paulo, v.36, n.4, 1999.

18. Pereira, A. S.; Pereira Filho, R. A. Doença Celíaca. Disponível em: <http://www.sgnsp.org.br/artigos.php?id=21>. Acesso em: 23 mai. 2015.

19. Protesi, R.; GandolFI, L. Doença celíaca: a afecção com múltiplas faces. Jornal de Pediatria, Rio de Janeiro, v. 81, n. 5, p. 357-358, 2005.

20. Castellón, L. Falsa raridade. Isto É, São Paulo, n. 1650, maio. 2001.

21. Cáceres, S; Quadrelli, A; SalinAS, G. Doença celíaca: o lado obscuro do trigo. Ciência Hoje, v. 16, n. 92, p.40-44, julho, 1993.

22. Rigatto, C. Entrevista: Dia Internacional do Celíaco. Nutrição em Pauta. Ano X, n. 53, mar/abril, 2002.

23. Canella-Rawls, S. Pão: arte e ciência. 3. ed. São Paulo: SENAC-SP, 2003. 320 p.

24. Korn, D. Vivendo sem Glúten para Leigos. Rio de Janeiro: Alta 
Books, 2010. 376 p.

25. Araújo, H. M. C.; Araújo, W. M. C.; Botelho, R. B. A.; Zandonadi, R. P. Doença celíaca: hábitos e práticas alimentares e qualidade de vida. Revista de Nutrição, Campinas, v. 33, n. 3, p. 467-474, 2010.

26. Esteller, M. S.; Amaral, R., Lannes, S. C. S. Effect of Sugar and Fat Replacers on the Texture of Baked Goods. Journal Texture Studies, Malden, v. 35, p. 383-393, 2004.

27. Tedrus, G. A. S; Ormenese, R. C. S. C; Speranza, S. M; Chang, Y. K; Bustos, F. M. Estudo da adição de vital glúten à farinha de arroz, farinha de aveia e amido de trigo na qualidade de pães. Rev. Ciência e Tecnologia de Alimentos, Campinas, v. 21, n. 1, p. $20-25,2001$.

28. Bobbio, P. A.; Bobbio, F. O. Química de Processamento de Alimentos. 3. ed., São Paulo: Varela, 1992. 232 p.

29. Arendt, E.K., Morrisey, A., Moore, M.M., Bello, F.D. Glutenfree Breads. In: _. Gluten-free Cereal Products and Beverages. Academic press, 2008. cap. 13, p. 289 -311.

30. Ferrari, M. C. Estudos de viabilidade sobre avaliação de qualidade de farinhas de trigo através de medidas das propriedades do glúten. 1998. 111 f. Dissertação (Mestrado em Tecnologia de Alimentos) - Universidade Estadual de Campinas, Campinas, 1998.

31. Castro, F. F. M.; Jacob, C. M. A.; Castro, A. P. B. M.; Yang, A. C. Alergia alimentar. Barueri, SP: Manole, 2010. 275 p.

32. Gisslen, W. Panificação e Confeitaria Profissionais. 5. ed. Barueri: Manole, 2011. 770 p.

33. Cauvain, S. P.; YOUNG, L. S. Tecnologia da Panificação. 2. ed. São Paulo: Manole, 2009. 440 p.

34. Racco, R. Glúten e obesidade, a verdade que emagrece. 1. ed. Rio de Janeiro: RRacco, 2008. 160 p.

35. Souza, T.C. Alimentos: Propriedades Físico-químicas. 2. ed. Rio de Janeiro: Cultura Médica, 2001. 240 p.

36. Damodaran, S.; Parkin, K. L.; Fennema, O. R. Química de Alimentos de Fennema. 4. ed., Porto Alegre: Artmed, 2010. $900 \mathrm{p}$.

37. Freeland-Graves, J. H. Foundations Of Food Preparation. 6. ed. Library of Congress Catologing-in-Publication Data, 1995. $768 \mathrm{p}$.

38. Brasil. Resolução RDC n 90, de 18 de outubro de 2000. Aprova o Regulamento Técnico para Fixação de Identidade e Qualidade de Pão. D.O.U. - Diário Oficial da União; Poder Executivo, Brasília, DF, 20 de outubro de $\mathbf{2 0 0 0 .}$

39. Gray, J. A.; Bemiller, J. N. Bread staling: molecular basis and control. Comprehensive Reviews in Food Technology, Malden, v. 2, p. 1-21, 2003.

40. Borges, J. T. S.; Pirozi, M. R.; Della Lucia, S. M.; Pereira, P. C.; Moraes, A. R. F.; Castro, V. C.. Utilização de farinha mista de aveia e trigo na elaboração de bolos. B. CEPPA, Curitiba, v.
24, n. 1, 145-162 p., jan./jun. 2006.

41. Hoseney, R. C. Principios de ciencia y tecnologia de los cereales. Zaragoza: Acribia, 1991. 330p.

42. El-Dash, A.; Cabral, L.C.; Germani, R. Tecnologia de farinhas mistas: uso de farinha mista de trigo e soja na produção de pães. v. 3. Brasília: EMBRAPA, 1994. 89 p.

43. Brasil. Portaria $n^{\circ} 354,18$ de julho de 1996. Aprova a Norma Técnica referente a Farinha de Trigo. D.O.U. - Diário Oficial da União; Poder Executivo, Brasília, DF, 1996.

44. Granotec Do Brasil. Disponível em: $<$ http://granotec.com.br $>$. Acesso em: 14 ago. 2015.

45. Queiroz, G. M. Determinação de propriedades termofísicas do pão francês durante o processamento de assamento. 2001. 179 f. Dissertação (Mestrado em Engenharia) - Escola Politécnica da Universidade de São Paulo, São Paulo, 2001.

46. Granotec Do Brasil. Formuladores de pré-misturas e panificação. Curitiba: Granotec do Brasil, Apostila. 1998. 90p.

47. Cauvain, S. P.; Young, L. S. Technology of breadmaking. 3. ed. New York: Springer, 2015. 408 p.

48. Pavanelli, A.P. Aditivos para panificação: conceitos e funcionalidade. Oxiteno S/A Indústria e Comércio. São Paulo, 2000. $6 \mathrm{p}$.

49. Pyler, E. J. Baking science and technology. 3. ed. Kansas: Sosland Publishing Co., v.1, 1988. 588 p.

50. Germani, R. Qualidade da farinha de trigo e panificação. In: Semana Acadêmica de Engenharia de Alimentos, Rio de Janeiro, Apostila 74p. 2003.

51. Matuda, T. G. Análise térmica da massa de pão francês durante os processos de congelamento e descongelamento: Otimização do uso de aditivos. 2004. 142 f. Dissertação (Mestrado em Engenharia) - Escola Politécnica da Universidade de São Paulo, São Paulo, 2004.

52. León, A.E.; Durán, E.; Barber, C. B. de. Utilization of Enzyme Mixtures To Retard Bread Crumb Firming. Journal of Agricultural and Food Chemistry, Kidlington, v. 50, n. 6, p. 1416-1419, 2002.

53. Walter, M.; Silva, L. P.; Emanuelli, T. Amido resistente: características físico-químicas, propriedades fisiológicas e metodologias de quantificação. Ciência rural, Santa Maria, v. 35, n. 4, p. 974-980, 2005.

54. Fitzgerald, M.A.; Mccouch, S.R.; HALL, R.D. Not just a grain of rice: the quest for quality. Trends in Plant Science, London, v. 14, p. 133-139, 2009.

55. Tester, R.F.; Karkalas, J.; Qi, X. Review: Starch composition fine structure and architecture. Journal of Cereal Science, London, v. 39, p. 151-165, 2004.

56. Coultate, T.P. Food the Chemistry of its Components. The Royal Society of Chemistry, 4. ed., Cambridge: RSC Paperbacks, 2002. 448 p. 
57. Borba, A. M.; Sarmento, S. B. S.; Leonel, M. Efeito dos parâmetros de extrusão sobre as propriedades funcionais de extrusados da farinha de batata-doce. Ciência e Tecnologia de Alimentos, Campinas, v. 25, n. 4, p. 835-843, 2005.

58. IBGE. Disponível em: $<$ http:// www.ibge.gov.br>. Acesso em: 28 jan. 2015.

59. Neiva, I. P; Andrade Júnior, V. C.; Viana, D. J. S.; Figueiredo, J. A.; Mendonça Filho, C. V.; Parrella, R. A. C.; Santos, J.B. Caracterização morfológica de acessos de batata-doce do banco de germoplasma da UFVJM, Diamantina. Horticultura Brasileira, Campinas, v. 29, p. 537-541, 2011.

60. Leonel, M.; Oliveira, M.A.; Filho, J.D. Espécies tuberosas tropicais como matérias-primas amiláceas (Tropical tubers as starchy raw materials). Revista Raízes Amidos Tropicais (RAT), Botucatu, v. 1, p. 49-68, 2005.

61. Miranda, J. E. C. De; França, F. H.; Carrijo, O. A.; Souza, A. F.; Pereira, W.; Lopes, C. A.; Dilva, J. B. C. A cultura da batata-doce. Brasília, DF: Embrapa /CNPH, 1995. 94 p.

62. Luengo, R. F. A.; Parmagnani, R. M.; Parente, M. R.; Lima, M. F. B. F. Tabela de composição nutricional das hortaliças. Brasília: EMBRAPA Hortaliças. 2000. 4 p.

63. Iwe, M. O.; Van Zuilichem, D. J.; Ngoddy, P. O.; Lammers, W. Amino acid and protein dispersibility index (PDI) of mixtures of extruded soy and sweet potato flours. LebensmittelWissenschaft Und Technologie, Amsterdam, v. 34, n. 2, p. 71-75, 2001.

64. Amante, E. R. Caracterização de amidos de variedades de mandioca (Manihot esculenta, Crantz) e de batata-doce (Ipomoea batatas). 2003. 109 f. Dissertação (Mestrado em Ciência e Tecnologia dos Alimentos) - Universidade Federal de Viçosa, Viçosa, 2003.

65. Noda, T.; Nishiba, Y.; Sato, T.; Suda, I. Properties of starches from several low-amylose rice cultivars. Cereal Chemistry, St Paul, v. 80, p. 193-197, 2003.

66. Gallant, D.J.; Bewa, H.; Buy, Q.H.; Bouchet, B.; Szylit, O.; Sealy, L. On ultrastructural and nutrional aspects of some tropical tuber starches. Starch-Starke, Weinheim, v. 34, n. 8, p. $255-262,1982$

67. Thomas, D. J.; Atwell, W. A. Starches. Saint Paul: Zagan Press, 1997. 93 p. (Zagan Press Handbook Series).

68. Santos, J. C. Dos; Souza, D. C. L.; Santana, M. M. De; Castro, A. A.; Silva, G. F. DA. Estudo da cinética de secagem de batata-doce (Ipomoea batatas). Revista Brasileira de Produtos Agroindustriais, Campina Grande, v. 14, n. 4, p. 323-328, 2012.

69. Alves, R. M. V., Ito, D., Carvalho, J. L. V., MELO, W. F., GODOY, R. L. O. Estabilidade de farinha de batata-doce biofortificada. Braz. J. Food Technol., Campinas, v. 15, n. 1, p. 59-71, jan./mar. 2012

70. Carvalho, F. M.; Santos, A.; Viana, A. E. S.; Lopes, S.C.; Egler, P.G. Avaliação da atividade poluidora da manipueira na bacia do Rio Santa Rita em Vitória da Conquista, Bahia. In: CONGRESSO BRASILEIRO DE MANDIOCA, 11, 2005. Resumos. Campo Grande. 2005.

71. Idris, N. A.; HA, C. M. C.; HASSAN, H.; EMBONG, M. S.; ABDULLAH, A. Performance evaluation of shortenings based on palm oil and butterfat in yellow cake. Fett/Lipid, Kuala Lumpur, v. 98, n. 4, p. 144-148, 1996.

72. Sammy, G. M. Sudies in composite flour. The use of sweet potato flour in Bread and pastry makin. Tropical agriculture, New Delhi, v. 47, n. 2, p. 115, 1970.

73. Vieira, N. R. A.; Santos, A. B.; Santana, E. P.; A Cultura do Arroz no Brasil. Santo Antônio de Goiás: Embrapa Arroz e Feijão, 1999. 633p.

74. CONAB. COMPANHIA NACIONAL DO ABASTECIMENTO. Disponível em: $<$ http://www.conab.gov. br/conteudos.php? $\mathrm{a}=1253 \& \mathrm{t}=>$. Acesso em: 13 ago. 2015.

75. Kennedy, G.; Burlingame, B.; Nguyen, N. Nutrient impact assessment of rice in major rice-consuming countries. International Rice Commission Newsletter, Roma, v. 51, p. 33-42, 2002.

76. Silva, E. M. M. Produção de macarrão pré-cozido à base de farinha mista de arroz integral e milho para celíacos utilizando o processo de extrusão. 118 f. Dissertação (Mestrado em Ciência) - Instituto de Tecnologia, Universidade Rural do Rio de Janeiro, Rio de Janeiro, 2007

77. Cardoso, M. B. Características tecnológicas e funcionais de farinhas mistas de arroz e trigo para elaboração de sopas. 2003. 88 f. Dissertação (Mestrado em Ciência e Tecnologia Agroindustrial) - Faculdade de Agronomia “"Eliseu Maciel”, Universidade Federal de Pelotas, Pelotas, 2003.

78. Walter, M.; Marchezan, E.; Avila, L. A. De. Arroz: composição e características nutricionais. Ciência Rural, Santa Maria, v. 38, n. 4, p. 1184-1192, 2008.

79. Shamai, K.; Bianco-Peled, H.; Shimoni, E. Polymorphism of resistant starch type III. Carbohydrate Polymers, Kidlington, v. 54, n. 3, p. 363-369, 2003

80. Nabeshima, h. A.; el-dash, A. Modificação química da farinha de arroz como alternativa para o aproveitamento dos subprodutos do beneficiamento do arroz. B. CEPPA, Curitiba, v. 22, n. 1, p. 107-120, 2004.

81. Polanco, I.; Molina, M.; Pietro, G.; Carraco, S.; Lama, R. Dieta y enfermedad celíaca. Alimentaria, Madrid, v. 33, n. 264, p. 91-93, 1995.

82. Elias, M. C.; Franco, D. F. Pós-Colheita e Industrialização de Arroz. In: Ariano Martins de Magalhães Júnior; Algenor da Silva Gomes; Alberto Baêta dos Santos. (Org.). Sistemas de Cultivo de Arroz Irrigado no Brasil. 1. ed. Pelotas: Embrapa Clima Temperado, 2006, v. 1, p. 229-240.

83. Embrapa.Disponível em <http://www.embrapa.gov.br/embrapa/ imprensa/noticias/2007/junho/4asemana/noticia $>2007$. Acesso em: 15 fev. 2015. 
84. Sivaramakrishnan, H. P.; Senge, B.; Chattopadhyay, P. K. Rheological properties of rice dough for making rice bread. Journal of Food Engineering, Kidlington, v. 62, n. 1, p. 37-45, 2004.

85. Clerici, M. T. P. S.; El-Dash, A. A. Farinha extrusada de arroz como substituto de glúten na produção de pão de arroz. Archivos Latino-americanos de Nutrición, Venezuela, v. 56, n. 3, p. 288-298, 2006.

86. Lazaridou, A.; Duta, D.; Papageorgiou, M.; Belc, N.; Biliaderis, C. G. Effects of hydrocolloids on dough rheology and bread quality parameters in gluten-free formulations. Journal of Food Engineering, Kidlington, v. 79, n. 3, p. 1033 1047, 2007.

87. Bonet, A.; Blaszczak, W.; Rosell, C. M. Formation of homopolymers and heteropolymers between wheat flour and several protein sources by transglutaminase catalyzed crosslinking. Cereal Chemistry, St Paul, v. 83, n. 6, p. 655-662, 2006.

88. Marco, C.; Pérez, G.; León, A. E.; Rosell, C. M. Effect of transglutaminase on protein eletrophoretic pattern of rice, soybean, and rice-soybean blends. Cereal Chemistry, St Paul, v. 85 , n. 1 , p. 59-64, 2008.

89. Marco, C.; Rosell, C. M. Effect of different protein isolates and transglutaminase on rice flour properties. Journal of Food Engineering, Kidlington, v. 84, n. 1, p. 132-139, 2008a.

90. Marco, C.; Rosell, C. M. Functional and rheological properties of protein enriched gluten free composite flours. Journal of Food Engineering, Kidlington, v. 88, n. 1, p. 94-103, 2008b.

91. Caballero, P. A.; Gómez, M.; Rosell, C. M. Improvement of dough rheology, bread quality and bread shelf-life by enzymes combination. Journal of Food Engineering. Oxford, v. 81, n. 1, p. $42-53,2007$

92. Gujral, H. S.; Rosell, C. M. Functionality of rice flour modified with a microbial transglutaminase. Journal of Cereal Science, London, v. 39, n. 2, p. 225-230, 2004.

93. Moore, M. M.; Heinbockel, M.; Dockery, P.; Ulmer, H. M.; Arendt, E. K. Network Formation in Gluten-Free Bread with Application of Transglutaminase. Cereal Chemistry, St Paul, v. 83 , n. 1 , p. 28-36, 2006.

94. Renzetti, S.; Bello, F. D.; Arentdt, E. K. Microstruture, fundamental rheology and baking characteristics of batters and breads from different gluten-free flours treated with a microbial transglutaminase. Journal of Cereal Science, London, v. 48, n. 1, p. 33-45, 2008.

95. Dors, G.C.; Castiglioni, G.L.; Augusto-Ruiz, W. Utilização de farinha de arroz na elaboração de sobremesa. Vetor, Rio Grande, v. 16, n. 2, p. 63-67, 2006.

96. Becker, F. S. Caracterização de farinhas cruas e extrusadas obtidas a partir de grãos quebrados de diferentes genótipos de arroz. 2010. 76 f. Dissertacão - (Mestrado em Ciência e Tecnologia de Alimentos) - Escola de Agronomia e Engenharia de Alimentos, Universidade Federal de Goiás, Goiânia, 2010.
97. Guimarães, F. I. T.; Caliari, M.; Soares Junior, M. S. Instrumental Analysis of Texture, Color and Acceptance of Instant Dessert Formulated with Broken-rice Grains. Food Science and Technology Research, Basel, v. 20, n. 4, p. 785792, 2014.

98. Tavares, J. A. S.; Soares Júnior, M. S.; Becker, F. S.; Costa, E. E. Mudanças funcionais de farinha de arroz torrada com micro-ondas em função do teor de umidade e do tempo de processamento. Ciência Rural, Santa Maria, v. 42, n. 6, p. 1102-1109, 2012.

99. Ferreira, S. M. Modificação enzimática da farinha de grãos quebrados de arroz para produção de alimento sem glúten. 2012. 169 f. Dissertação (Mestrado em Ciência e Tecnologia de Alimentos) - Universidade Federal de Goiás, Goiânia, 2012.

100.Moura, C. M. A. Qualidade de farinhas pré-gelatinizadas e macarrões formulados com arroz (Oryza sativa L.) e linhaça (Linum usitatissimun L.). 2011. 178 f. Dissertação (Mestrado em Ciência e Tecnologia de Alimentos) - Universidade Federal de Goiás, Goiânia, 2011.

101.Soares Júnior, M. S.; Santos, T. P. B.; Pereira, G. F.; Minafra, C. S.; Caliari, M.; Silva, F. A. Development of extruded snacks from rice and bean fragments. Semina: Ciências Agrárias, Londrina, v. 32, p. 189-198, 2011.

102.Carvalho, W. T.; Soares Junior, M. S.; Reis, R. C.; Velasco, P.; Bassinello, P. Z.; Caliari, M.. Características físico-químicas de extratos de arroz integral, quirera de arroz e soja. Pesquisa Agropecuária Tropical (Online), Goiânia, v. 41, n. 3, p. 421-429, 2011.

103.Soares Júnior, M. S.; Bassinello, P. Z.; Caliari, M.; Reis, R. C.; Lacerda, D. B. C. L.; Koakuzu, S. N. Development and chemical characterization of flour obteined from mesocarpo of "pequizeiro" fruit. Ciência e Tecnologia de Alimentos, Campinas, v. 30, n. 4, p. 949-954, 2010

104.Sousa, G. M.; Soares Júnior, M. S.; Yamashita, F. Active biodegradable films produced with blends of rice flour and poly (butylene adipate co-terephthalate): Effect of potassium sorbate on film characteristics. Materials Science \& Engineering. C, Biomimetic Materials, Sensors and Systems, Amsterdam, v. 33, p. 3153-3159, 2013.

105.Souza, T. A. C.; Soares Junior, M. S.; Campos, M. R. H.; Souza, T. S. C.; Dias, T. D.; Fiorda, F. A. Bolos sem glúten a base de arroz quebrado e casca de mandioca. Semina: Ciências Agrárias, Londrina, v. 34, n. 2, p. 717-728, 2013.

106.Hudson, E. No longer niche. Baking \& Snack International, Montpellier, v. 5, n. 4, p. 20-21, 2009.

107.Thompson, T.; Dennis, M.; Higgins, L. A.; Lee, A. R.; Sharrett, M. K. Gluten-free diet survey: are Americans with coeliac disease consuming recommended amounts of fibre, iron calcium and grain foods? Journal of Human Nutrition and Dietetics, Malden, v. 18, p. 163-169, 2005.

108.Alvarez-Jubete, L.; Auty, M.; Arendt, E. K.; Gallagher, E. Baking properties and microstructure of pseudocereal Xours in gluten- 
free bread formulations. Eur Food Res Technol, New York, v. 230, p. 437-445, 2010.

109.Breshears, K. L.; Crowe, K. M. Sensory and Textural Evaluation of Gluten-Free Bread Substituted With Amaranth and Montina ${ }^{\mathrm{TM}}$ Flour. Journal of Food Research; Bratislava, v. 2, n. 4, p. 1 - 10, 2013.

110.Capriles, V. D.; Arêas, J. A. G. Avanços na produção de pães sem glúten: aspectos tecnológicos e nutricionais. B. CEPPA, Curitiba, v. 29, n. 1, p. 129-136, 2011.

111. Crockett, R.; Ie, P.; Vodovotz, Y. How do xanthan and hydroxypropyl methylcellulose individually affect the physicochemical properties in a model gluten-free dough? Journal of Food Science, Malden, v. 76, n. 3, p. 274-282, 2011a.

112.Purhagen, J. K.; Sjöö, M. E.; Eliasson, A. C. The anti-staling effect of pre-gelatinized flour and emulsifier in gluten-free Bread. European Food Research and Technology, New York, v. 235, p. 265-276, 2012.

113.Borges, J. T. S., Ascheri, J. L. R., Ascheri, D. R., Nascimento, R. E, Freitas, A. S. Propriedades de cozimento e caracterização físico-química de macarrão pré-cozido à base de farinha integral de quinoa (Chenopodium quinoa Willd) e de farinha de arroz (Oryza sativa, L) polido por extrusão termoplástica. B. CEPPA, Curitiba, v. 21, n. 2, p. 303-322, 2003.

114. Anton, A. A., Artifield, S. D. Hydrocolloids in gluten-free breads: A review. International Journal of Food Sciences and Nutrition, Abingdon, v. 59, n. 1, p. 11-23, 2008.

115.Crockett, R.; Ie, P.; Vodovotz, Y. Effects of soy protein isolate and egg white solids on the physicochemical properties of gluten-free Bread. Food Chemistry, Kidlington, v. 129, p. 84-91, 2011b.

116. Gambus, H.; Sikora, M.; Ziobro, R. The effect of composition of hydrocolloids on properties of gluten-free bread. Acta Scientiarum Polonorum, Lublin, v. 6, n. 3, p. 61-74, 2007.

117.Padalino, L.; Mastromatteo, M.; Lecce, L.; Cozzolini, F.; Del Nobile, M. A. Manufacture and characterization of gluten-free spaghetti enriched with vegetable flour. Journal of Cereal Science, London, v. 57, p. 333- 342, 2013.

118. Sánchez, H. D.; Osella, C. A.; De La Torre, M. A. Optimization of Gluten-Free Bread Prepared from Cornstarch, Rice Flour, and Cassava Starch. Journal of Food Science, Malden, v. 67, n. 1, p. 416-419, 2002.

119. Sciarini, L. S.; Ribotta, P. D.; Leon, A. E.; Perez, G. T. Incorporation of several additives into gluten free breads: Effect on dough properties and bread quality. Journal of Food Engineering, Kidlington, v. 111, p. 590-597, 2012.

120.Brasil. Agência Nacional de Vigilância Sanitária. RDC nº 45, de 03 de novembro de 2010. Dispõe sobre aditivos alimentares autorizados para uso segundo as Boas Práticas de Fabricação (BPF). Diário Oficial da República Federativa do Brasil, Brasília, DF, 2010. Disponível em: < http://www.anvisa.gov.br/e-legis/>. Acesso em: 09 jul. 2015.

121.Brasil. Resolução RDC no 383, de 5 de agosto de 1999. Aprova o Regulamento técnico que aprova o uso de aditivos alimentares, estabelecendo suas funções e seus limites máximos para a categoria de alimentos 7 - produtos de panificação e biscoitos. Diário Oficial da República Federativa do Brasil, Brasília, DF, 09 ago. 1999. Disponível em:<http://portal.anvisa.gov.br/wps/wcm/ connect/faa2fb0043447422ba93bbff1ba42680/Resolu\%C3\%A7\% $\mathrm{C} 3 \% \mathrm{~A} 3 \mathrm{o}+\mathrm{n} \% \mathrm{C} 2 \% \mathrm{BA}+383,+\mathrm{de}+05+\mathrm{de}+$ agosto + de $+1999+$ biscoi to.pdf?MOD=AJPERES $>$. Acesso em 09 abr. 2012.

122.Miller, R. A.; Hoseney, R. C. The Role of Xanthan Gum in White Layer Cakes. Cereal Chemistry, St Paul, v. 70, p. 585-588, 1993.

123.Morris, V. J. Science, structure and applications of microbial polysaccharides. In: Gums and Stabilizers for the Food Industry. Phillips, G.O., Williams, P.A.; Wedlock, D.J. (Eds.), Oxford, p. 315- 328, 1990.

124.Cubero, N.; Monferrer, A.; Villalta, J. Aditivos Alimentarios. Madrid: S.A. Mundi-Prensa Libros, 2002. 240 p.

125.Imenson, A. Food Stabilisers, Thickeners and Gelling Agents. Oxford: Blackwell Publishing, 2010, 368 p.

126.Phillips, G.O.; Williams, P.A. Handbook of Hydrocolloids. 2, ed., Cambridge: Woodhead Publishing, 2009. 948 p.

127.Gallagher, E.; Gormley, T.R.; Arendt, E.K. Recent advances in the formulation of gluten-free cereal-based products. Trends in Food Science and Technology, London, v. 15, p. 143-152, 2004.

128.Mc Carthy, D. F.; Gallagher, E.; Gormley, T. R.; Schober, T. J.; Arendt, E. K. Application of response surface methodology in the development of gluten-free bread. Cereal Chemistry, St Paul, v. 82, p. 609-615, 2005

129.Schober, T. J.; Messerschmidt, M.; Bean, S. R.; Park, S. H.; Arendt, E. K. Gluten-free bread from sorghum: quality differences among hybrids. Cereal Chemistry, St Paul, v. 82, p. 394-404, 2005.

130.Selomulyo, V. O.; Zhou, W. Frozen bread dough: Effects of freezing storage and dough improvers. Journal of Cereal Science, London, v. 45, p. 1-17, 2007.

131.Gimeno, E.; Moraru, C. I.; Kokini, J. L. Effect of xanthan gum and $\mathrm{CMC}$ on the structure and texture of corn flour pellets expanded by microwave heating. Cereal Chemistry, St Paul, v. 81, n. 1, p. 100-107, 2004.

132.Rochefort, W. E.; Middleman, S. Rheology of Xanthan Gum: Salt, Temperature, and Strain Effects in Oscillatory and Steady Shear Experiments. Journal of Rheology, Melville, v. 31, p. 337-369, 1987.

133.Luvielmo, M. M.; Scamparini, A.R.P. Goma xantana: produção, recuperação, propriedades e aplicação. Estudos Tecnológicos, São Leopoldo, v. 5, n 1, p. 50-67, 2009.

134.Faria, S.; Petkowicz, C. L. De O.; Morais, S. A. L. De; Terrones, M. G. H.; Resende, M. M. De; França, F. P. De; Cardoso, V. L. Characterization of xanthan gum produced from sugar cane broth. Carbohydrate Polymers, Kidlington, v. 86, n. 2, p. 469-476, 2011.

135.Guarda, A.; Rosell, C. M.; Benedito, C.; Galotto, M.J. Different hydrocolloids as bread improvers and antistaling agents. Food 
Hydrocolloids, Oxford, v. 18, p. 241-247, 2004.

136.Rodge, A.B.; Sonkamble, S.M.; Salve, R.V.; Syed, I.H. Effect of hydrocolloid (guar gum) incorporation on the quality characteristics of bread. Journal Food Process Technology, v. 3, p. 1-7, 2012.

137.Koksel, H. F. Effects of xanthan and guar gums on quality and staling of gluten free cakes baked in microwave-infrared combination oven. 2009. 146 f. Dissertação (Mestrado em Engenharia Alimentar) - Escola Superior de Ciências Naturais e Aplicada, Universidade Técnica do Oriente Médio, 2009. Disponível em < etd.lib.metu.edu.tr/upload/12610410/index.pdf $>$ Acesso em: 25 ago. 2015.

138.Sciarini, L.S.; Ribotta, P.D.; León, A.E.; Pérez, G.T. Effect of hydrocolloids on gluten-free batter properties and bread quality. International Journal of Food Science and Technology, Malden, v. 45, p. 2306-2312, 2010.

139. Bortolotto, D. F. J. Estudo do comportamento da viscosidade de sistemas de carboximetilcelulose de sódio e diferentes componentes nos produtos para indústria alimentícia. 2009. 42 f. Monografia (conclusão do Curso de Licenciatura Plena em Química) - Faculdade de Ciências, Universidade Estadual Paulista "Júlio de Mesquita Filho", Bauru, 2009.

140.Katzbauer, B. Properties and applications of xanthan gum. Polymer Degradation and Stability, Kidlington, v. 59, p. 81-84, 1998.

141. Children's Boston Group. The gluten-free diet: a guide for teens. Disponível em: <http://www.youngmenshealthsite.org/gluten free_diet.html>. Acesso em: 22 mar. 2015.

\section{Vilmara A. Franco*i \& Flávio A. Silva ${ }^{2}$}

\footnotetext{
${ }^{1}$ Instituto SENAI de Tecnologia em Alimentos e Bebidas,- Rua Professor Lázaro Costa nº 348, Vila Canaã, CEP: 74415-420, Goiânia, Goiás, Brasil.

${ }^{2}$ Universidade Federal de Goiás, Departamento de Engenharia de Alimentos, Goiânia, 74690-900.

*E-mail: vilmara.senai@gmail.com
} 